\section{8 錯塩の性質}

無水の状態で銅 (II) と $n$-ブチルアルドキシムから得 られる $\left[\mathrm{CuCl}_{2} \cdot\left(n-\mathrm{C}_{4} \mathrm{H}_{8} \mathrm{NOH}\right)_{4}\right]^{2)}$ 注可視部の $\lambda_{\max }=$ $725 \mathrm{~m} \mu$ で, 水にふれると $\lambda_{\max }=640 \mathrm{~m} \mu$ の本報で述べ た抽出層の吸収と全く一致する錯塩に変わる.すべて酸 によって最終的には無色となる2).この錯塩の単離結晶 化は成功しなかった。抽出の際共存する陰イオンが, 水 酸イオン, 炭酸イオン, 酢酸イオン, リン酸イオンのい ずれかにより肉眼的にはやや色調が異なり，吸光度の大

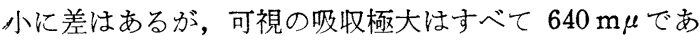
った。上記の錯塩とは異なるが近いものかもしれない。

\section{9 実験 の部}

試薬は特級，ないものは 1 級を使用した・nーブチル アルドキシムは常法によって合成し, 蒸留して精製し た. 日立 EPU-2A および EPS-2 型光電分光光度計を 使用した。経時变化には $20 \pm 1^{\circ} \mathrm{C}$ の水浴を用いた。

終りに，で援助を賜わった滝浦絜教授に深謝する。

\section{交献}

1) S. H. Simonsen, H. M. Burnett : Anal. Chem., 27, 1336 (1955).

2) M. Masui, K. Hotta : Chem. Pharm. Bull., 12, 564 (1964).

（昭和 39 年 7 月 7 日受理）

\section{チオシアン酸によるモリブデン定量に おける共存金属イオンの影響}

西田宏*

チオシアン酸によるモリブデンの定量における共存金 偊イオンの影響を考察した。

いま金属イオンの酸性の強さ12) 力の強さを表わしているものと考えられるので, チオシ アン酸錯掹における金属イオンの酸性の強さと, その吸 収帯および発色の強さとの関係を調べて見ると, 一般に 酸性の強い金属イオンの錯塩ほど,

i ）吸収帯がより浅色的である13).

ii）発色の強さが大きくなる(より濃色的である). ということがわかった。

したがってモリブデンの定量の際，共存金属イオンの 影響の大きさの順序は，おのおのの金属イオンの酸性の
強さの順序であることを明らかにした。

これらのことは, チオシアン酸による金属イオンの定 量1 11) の適否, あるいは共存物質の影響の推定に利用 するとができる。

\section{1 試薬および装置}

チオシアン酸アンモニウム溶液: $10 \%$ 水溶液.

チオシアン酸アンモニウムアセトン溶液 : チオシアン 酸アンモニウム飽和アセトン溶液.

塩化第一スズ溶液 : 塩化第一スズ $1 \mathrm{~g}$ を塩酸 $(1: 1)$ $40 \mathrm{~m} l$ 亿溶解し，水で $100 \mathrm{ml}$ とする.

装置は東京光電（株）製二重分光光度計 ANA 12 型, $1 \mathrm{~cm}$ 液そうを用いた。

2 チオシアン酸によるモリブデン定量にお ける共存金属イオンの影響とその考察

$0.2 \mathrm{mg}$ のモリブデンを含む溶液を $100 \mathrm{ml}$ メスフラス コにとり，これにいるいるの金属イオンを加え，水で 10 $\mathrm{m} l$ とする. これに硫酸 $10 \mathrm{~m} l$ を加え, 水冷したのち水 で 40〜 $60 \mathrm{ml}$ にうすめ, 塩化第一スズ溶液 $0.2 \mathrm{ml}$, チオ シアン酸アンモニウム溶液 $20 \mathrm{~m} l$ を加え, 水で標線まで うすめ, 振り混ぜたのち 30 分〜 1 時間放置してモリブ デンを発色させる ${ }^{14)}$. この溶液の一部を液そうにとり， $460 \mathrm{~m} \mu$ における吸光度を測定し，共存金属イオンの影 響を調べた（Table I ）。

Table I の金属イオンの分子吸光係数を Table II に示した.

Table I チオシアン酸によるモリブデン定量に 扣ける共存金属イオンの影響

\begin{tabular}{cccc}
\hline \hline 共存金属イオン & $\begin{array}{c}\text { 誤差を与えた共存金属 } \\
\text { イオンの量 }(\mathrm{mg})\end{array}$ & $\begin{array}{c}\text { JIS } \\
\text { 許容限度 }\end{array}$ \\
\hline & 諡差 $+0.5 \%$ & $+1 \%$ & $\mathrm{mg}$ \\
$\mathrm{Ni}^{2+}$ & 29 & 58 & 25 \\
$\mathrm{Cr}^{3+}$ & 3.4 & 7.0 & 4 \\
$\mathrm{~V}^{3+}$ & 0.58 & 1.2 & 0.5 \\
$\mathrm{Co}^{2+}$ & 5.0 & 10 & 5 \\
\hline
\end{tabular}

$\mathrm{Mo}^{5+}: 0.200 \mathrm{~g}, \quad \mathrm{NH}_{4} \mathrm{NCS}: 0.14 \mathrm{~mol} / l, \quad 460 \mathrm{~m} \mu$ で測定

Table II チオシアン酸による金属イオンの 発色の強さの比較

\begin{tabular}{llcc}
\hline \multirow{2}{*}{ イオン } & 添加金属塩 & \multicolumn{3}{c}{ 分子吸光俰数 } \\
\cline { 3 - 4 } & & $\lambda_{460 \mathrm{~m} \mu}$ & $\lambda_{\max }$ \\
\hline $\mathrm{Co}^{2+}$ & $\mathrm{Co}\left(\mathrm{NO}_{3}\right)_{2}$ & 4.8 & $53.5(630 \mathrm{~m} \mu)$ \\
$\mathrm{Ni}^{2+}$ & $\mathrm{Ni}\left(\mathrm{NO}_{3}\right)_{2}$ & 1.0 & $6.08(400 \mathrm{~m} \mu), 4.17(690 \mathrm{~m} \mu)$ \\
$\mathrm{Cr}^{3+}$ & $\mathrm{Cr}_{2}\left(\mathrm{SO}_{4}\right)_{3}$ & 14.8 & $15.88(440 \mathrm{~m} \mu), 9.65(585 \mathrm{~m} \mu)$ \\
$\mathrm{V}^{5+}$ & $\mathrm{NH}_{4} \mathrm{VO}_{3}$ & 88.5 & $408.0(400 \mathrm{~m} \mu), 22.0(600 \mathrm{~m} \mu)$ \\
$\mathrm{Fe}^{3+}$ & $\mathrm{Fe}_{2}\left(\mathrm{SO}_{4}\right)_{3}$ & - & $1.12 \times 10^{4}(480 \mathrm{~m} \mu)$ \\
$\mathrm{Mo}^{5+}$ & $\left(\mathrm{NH}_{4}\right)_{6} \mathrm{Mo}_{7} \mathrm{O}_{24}$ & $8.64 \times 10^{3}$ & - \\
$\mathrm{W}^{5+} \dagger \dagger$ & $\mathrm{Na}_{2} \mathrm{WO}_{4}$ & - & $9.20 \times 10^{3}(400 \mathrm{~m} \mu)$ \\
\hline
\end{tabular}

†塩化第一スズ溶液を加えない。

$\dagger$ 硫酸 $10 \mathrm{~m} l$, 塩酸 $20 \mathrm{~m} l$ および㙁化第一スズ 2 水塩 $3 \mathrm{~g}$ を加える7). 
また, Table II における分子吸光俰数の 対数と, 金属イオンの酸性の強さ，すなわち $\mathrm{M}^{n+}+\mathrm{H}_{2} \mathrm{O} \rightleftarrows$ $\mathrm{MOH}^{(n-1)+}+\mathrm{H}^{+}$の反応式に打汀平衡定数 $K$ の逆対 数値 $\mathrm{pK}^{12)}$ との関係を Fig. 1 に示した。

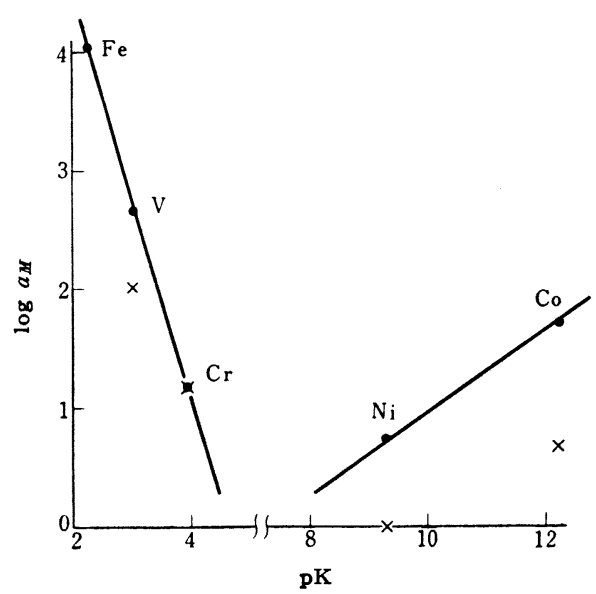

Fig. 1 分子吸光係数と金属イオンの酸性の強さの 関係

$a_{M}$ : 分子吸光保数 - $\lambda_{\max } \times \lambda_{460 \mathrm{~m} \mu}$

Table II および Fig. 1 に見られるように，金属イ オンの酸性が強いほど，吸収带がより浅色的となり，ま た分子吸光係数が大きくなる．したがって，モリブデン 定量に打いて共存金属イオンの影響の大きさの順序は $\mathrm{V}^{3+}, \mathrm{Cr}^{3+}, \mathrm{Co}^{2+}, \mathrm{Ni}^{2+}$ となり，これは $\mathrm{pK}$ の大きさの 順序である.

また，アセトン溶液における発色の強さを比較してみ た. 操作は Crouthamel らの方法3) に従った. この結 果を Table III に示す.

Table III アセトン溶液に扣けるチオシアン酸に よる金属イオンの発色の強さの比較

\begin{tabular}{|c|c|c|c|}
\hline \multirow{2}{*}{ イオンの種類 } & \multicolumn{2}{|c|}{ 分子吸光係数 $\times 10^{4}$} & \multirow{2}{*}{$\begin{array}{c}\text { 許容限度 } \\
(\mathrm{mg})\end{array}$} \\
\hline & $\lambda_{460 \mathrm{~m} \mu}$ & $\lambda_{\max }$ & \\
\hline $\mathrm{Nb}^{5+}$ & 0.7 & $3.8(417 \mathrm{~m} \mu)^{4)}$ & 0.0013 \\
\hline $\mathrm{Ti}^{4+}$ & 1.5 & $7.8(400 \mathrm{~m} \mu)^{4)}$ & 0.0003 \\
\hline $\mathrm{Mo}^{5+}$ & $1.87^{3)}$ & & - \\
\hline$W^{5+}+\dagger$ & - & $1.76(398 \mathrm{~m} \mu)^{3)}$ & - \\
\hline $\mathrm{Fe}^{3+\dagger}$ & - & $2.22(470 \mathrm{~m} \mu)$ & - \\
\hline $\mathrm{V}^{3+}$ & 0.23 & $1.18(400 \mathrm{~m} \mu)^{4)}$ & 0.002 \\
\hline $\mathrm{Cu}^{2+}+$ & - & $0.18(380 \mathrm{~m} \mu)$ & - \\
\hline $\mathrm{Pb}^{2+}$ & 0 & $0.23(322 \mathrm{~m} \mu)$ & - \\
\hline $\mathrm{Ni}^{2+}$ & 0.0003 & $0.002(400 \mathrm{~m} \mu)$ & 1.93 \\
\hline $\mathrm{Co}^{6+}$ & 0.027 & $0.17(630 \mathrm{~m} \mu)$ & 0.021 \\
\hline
\end{tabular}

†塩化第一スズ溶液を加えない。

††交献 3) の方法による（タングステンの定量） $60 \%$ (容液) アセトン 溶液. $\quad 0.6 \mathrm{~mol} / l \mathrm{NH}_{4} \mathrm{NCS}$.
同椂に Table III に打ける分子吸光俰数の対数と, 金属イオンの酸性の強さ $\mathrm{pK}$ との関係を Fig. 2 に示し た。

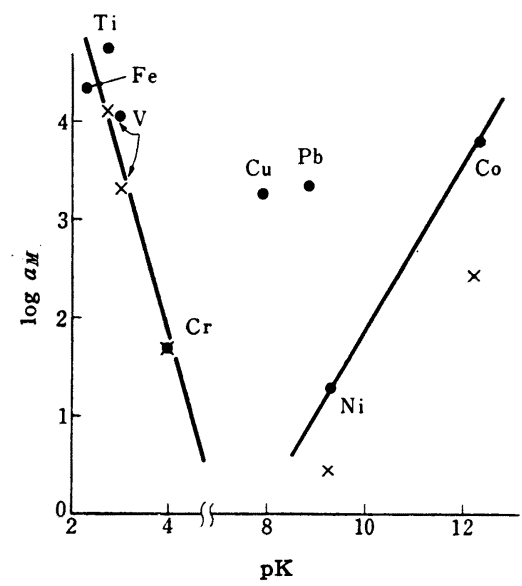

Fig. 2 アセトン溶液に打けるチオシアン酸による 金属イオン発色の強さと酸性の強さの関係 $a_{M}:$ 分子吸光係数

アセトン溶液においても同様に $460 \mathrm{~m} \mu$ における分子 吸光係数の大きさの順序は, 金属イオンの酸性の強さの 順序に従い，モリブデン定量に打ける共存金属イオンの 影響の大きさの順序でもある.

ここで Fig. 1 および Fig. 2 を比較して, ニオブ, チタンなど水溶液ではほとんど発色しない金属イオン が，アセトンの添加によって著しく発色の強さが増加す ることがわかる．このように周期表において族の番号と 等しい原子価の元素は, 水溶液では水和の影響が大き く, 発色の強さが低いものと思われる。また，これらの 錯塩注第一吸収帯を欠き13), 吸収帯が短波長側にずれて いる.

また銅，鉛などの水溶液でチオシアン酸により沈殿を 生ずるものは, アセトン溶液では $\mathrm{pK}$ が大きい割合に, 分子吸光係数が大きい.このように，アセトンなど水よ り極性の低い溶媒を加えたとき，水溶液のときとは異な った現象を生じ，モリブデン，バナジウム，クロムなど のグループ, ニオブ, チタンなどのグループおよび銅, 鉛などのグループと三つにわけて考察し，それぞれの関 係を調べる必要があろう.

また金属イオンの酸性の強さは, その錯塭の安定度の 推定にも利用できる。たとえば，金属の EDTA 錯塩の 安定度定数と, 金属イオンの酸性の強さ $(\mathrm{pK})$ は, アル ミニウムなどの例外はあるが直線関係を示している。 


\section{交献}

1）太秦康光 : 日化， 59，655，1047 (1938)； 62, 496 (1941).

2）池田重良：日化，77，79，81（1956）； 79，152 (1958).

池田重良：本誌，2，219（1953）.

3) C. E. Crouthame1, C. E. Johnson : Anal. Chem., 26, 1284 (1954).

4) C. E. Crouthamel, B. E. Hjeete, C. E. Johnson: ibid., 27, 509 (1955).

5) C. E. Crouthamel, C. E. Johnson : ibid., 24, 1780 (1952).

6) C. E. Crouthamel : ibid., 29, 1756 (1956).

7) H. Freund, L. M. Wright, R. K. Brooksier: ibid., 23, 781 (1951).

8) G. E. Markle, D. F. Boltz : ibid., 26, 447 (1954).

9) 小玉数信 : 本誌, 4, 447 (1955).

10) JIS G 1218.

11）岡 好良：“実験化学講座”, 第 15 巻, p. 80 (1963).

12）曾根興三，田中元治訳 (G. シャルロ一著)：“定 性分析化学”, 上, p. 201，301; 下, p. 244, $254,269,287,291,303,309,340,346$ (1961), (共立出版)。

13）槌田竜太郎：“金属化合物の色と構造”, p. 144 (1947).

14）西田 宏: 本誌, 12, 397 (1963).

（昭和 39 年 4 月 16 日受理） 